\title{
Chemical and Isotopic Composition of Water and Gas Phases from Mukhen Spa (Far East of Russia)
}

\author{
N. A. Kharitonova ${ }^{1,2}$, G. A. Chelnokov1, I. V. Bragin'1, 0. V. Chudaev ${ }^{1}$ \\ ${ }^{1}$ Far East Geological Institute, Far East Branch, Russian Academy of Sciences, Vladivostok, Russia \\ ${ }^{2}$ Moscow State University, Moscow, Russia \\ Email: tchenat@mail.ru
}

Received 1 April 2015; accepted 10 July 2015; published 17 July 2015

\begin{abstract}
This study presents new chemical and isotopic data on the two types of cold high $\mathrm{pCO}_{2}$ groundwaters located in the Mukhen deposit (Far East of Russia). The first type belongs to $\mathrm{HCO}_{3}-\mathrm{Ca}-\mathrm{Mg}$ waters with a relatively low TDS (up to $1.7 \mathrm{~g} / \mathrm{l}$ ) and high concentrations of $\mathrm{Fe}^{2+}, \mathrm{Mn}^{2+}, \mathrm{Ba}^{2+}$, and $\mathrm{SiO}_{2}$. The second type is of $\mathrm{HCO}_{3}-\mathrm{Na}$ water with high TDS (up to $14 \mathrm{~g} / \mathrm{l}$ ) and elevated $\mathrm{Li}^{+}, \mathrm{B} \mathrm{Sr}^{2+}, \mathrm{Br}^{-}$, and $\mathrm{I}^{-}$. New isotopic data of water $\left(\delta^{18} \mathrm{O}, \delta \mathrm{D}\right.$ and $\left.{ }^{3} \mathrm{H}\right)$ and gas $\left(\delta^{13} \mathrm{C}_{\mathrm{TIC}}\right)$ phases along with a detailed geological and hydrogeological investigation of the study area allowed identifying genesis of both the mineral waters. The residence time of groundwaters were calculated as well. It was established that the origin of the high $\mathrm{pCO}_{2}$ groundwaters was caused by active faulting and $\mathrm{CO}_{2}$ venting in the subsurface zone.
\end{abstract}

\section{Keywords}

Hydrogeochemistry, Mineral Waters, Carbon Dioxide, Isotopes, Far East

\section{Introduction}

In the Russian Far East (Khabarovsky krai) the Mukhen spa located in the southern part of the Khabarovsk krai, $100 \mathrm{~km}$ east of the town of Khabarovsk (Figure 1). This spa is unique due chemical composition of groundwater: two absolutely different type of cold $\left(7^{\circ} \mathrm{C}\right) \mathrm{CO}_{2}$-rich mineral waters (Ca-Mg- $\mathrm{HCO}_{3}$ and $\mathrm{Na}-\mathrm{HCO}_{3}$ ) issue from drilled wells in the same area. Both types of water are used by local spas. Ca-Mg- $\mathrm{HCO}_{3}$ type is shallow water (100 $\mathrm{m}$ deep), whereas $\mathrm{Na}-\mathrm{HCO}_{3}$ is relatively deep (150 m deep). The calcium-magnesium type demonstrates a relatively low TDS (up to $1.7 \mathrm{~g} / \mathrm{l}$ ) and elevated contents of $\mathrm{Fe}, \mathrm{Mn}, \mathrm{Ba}$, and $\mathrm{SiO}_{2}$, while the sodium water exhibits high TDS (up to $14 \mathrm{~g} /$ ) and enrichment in $\mathrm{Li}, \mathrm{B}, \mathrm{Sr}, \mathrm{Br}$, and I.

The purpose of this study is to elucidate a genesis of water and gas phase of this spa and identify processes that control the chemical evolutions of relatively deep $\mathrm{Na}-\mathrm{HCO}_{3}$ groundwater from shallow Ca-Mg- $\mathrm{HCO}_{3}$ groundwater in the Punchi River catchment area of the northern Sikhote-Alin mountains in Russia's Far East.

How to cite this paper: Kharitonova, N.A., Chelnokov, G.A., Bragin, I.V. and Chudaev, O.V. (2015) Chemical and Isotopic Composition of Water and Gas Phases from Mukhen Spa (Far East of Russia). Journal of Geoscience and Environment Protection, 3, 6-13. http://dx.doi.org/10.4236/gep.2015.35002 


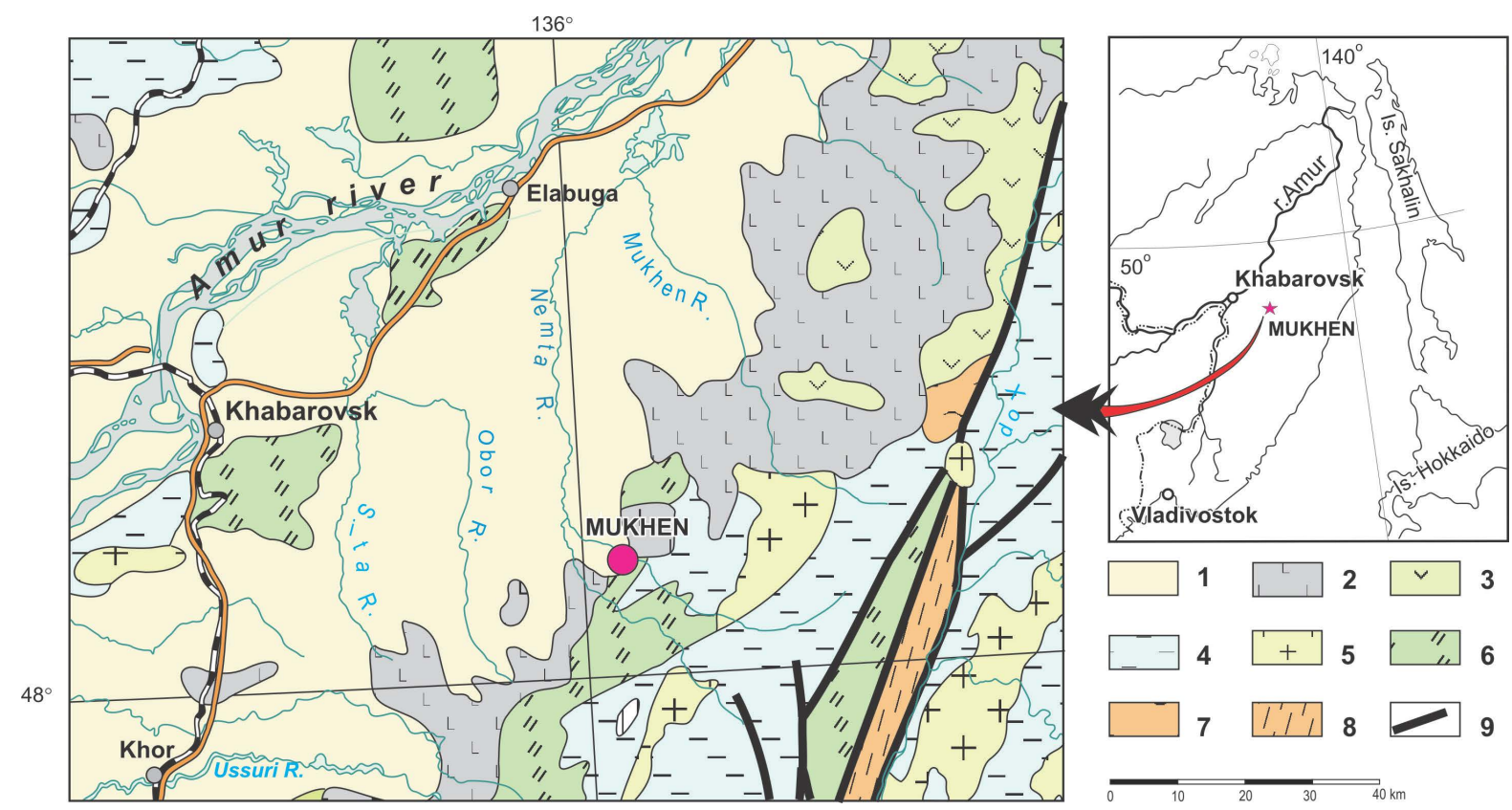

Figure 1. Location and geological setting of the Mukhen spa. (1) Quaternary alluvial deposits; (2) Pliocene-Quaternary basalts; (3) Early Cretaceous andesites; (4) Lower Cretaceous terrigenous deposits; (5) Early Cretaceous granites; (6) Jurassic volcanogenic-cherty-terrigenous deposits; (7) Triassic volcanogenic-terrigenous sediments; (8) Triassic gneiss; (9) faults.

\section{Geology and Hydrogeology}

The Muhen River catchment lies in the northern part of the Sikhote-Alin mountains system on the boundary zone of the Sikhote-Alin faulted belt and the Middle-Amur Cenozoic depression, at the north-eastern end of the Pereslavian graben.

The rocks exposed in the study region range from Mesozoic to modern. The Mesozoic sedimentary rocks outcrop to the east of the study area and include sandstone, siltstone and shale. The sandstone is generally quite porous and permeable but often pores space has been infilled with clay minerals and carbonate minerals. The deep aquifer is hosted in the upper fractured zone of this sediment. The Oligocene-Miocene rocks consist of approximately $40 \mathrm{~m}$ of moderate sorted sand, gravel and rabble with coal-beds and bodies of dolerite and basalt. The shallow stratal water is hosted here. The main recharge zone of this water occurs in the north of basin where the sediment complex outcrops (Thepkaia et al., 2005) [1].

The sedimentary rocks are overlapped by Miocene-Quaternary basalts with thickness of $50-400 \mathrm{~m}$. The basalts exhibit slight weathering and are characterized by very low permeability, with limited and superficial water circulation. The main minerals are plagioclase, pyroxene and olivine.

Alluviation associated with the Muhen River system is widespread in this area. It consists of terrestrial poorly sorted sand and gravel with stone, siltstone and clay and reaches a thickness up to $15 \mathrm{~m}$.

Numerous tectonic faults are spread across the study area. Punchi fault is the largest one. It is located under the cap of the Miocene-Quaternary basalts in southeast trend. The width of the fault zone is not less then 150 $200 \mathrm{~m}$.

\section{Sampling and Analytical Methods}

The study of the mineral waters and gases was conducted from 2000 to 2013 yy. Water samples were analyzed for major, trace and rare-earth elements (REE). The variable parameters were measured in situ, and the samples were filtered through $0.45 \mathrm{~m}$ membrane filters. The samples for isotopic analysis $\left(\delta^{18} \mathrm{O}\right)$ and $\left[\delta^{2} \mathrm{H}\right)$ were not filtered and collected in a glass. The samples for tritium determination were taken in plastic bottles without preliminary oxidation and filtration.

Major cations and anions were analyzed by ion chromatography. Trace element and REE concentrations in groundwater and bedrock samples were determined by ICP-MS analysis (Agilent 4500 and 7500c). Analytical 
precision for the REEs was better than 5\% RSD. The gas studies were carried out using gas chromatography. The stable isotopes of $\delta^{2} \mathrm{H}, \delta^{18} \mathrm{O}$, and $\delta^{13} \mathrm{C}$ in aqueous and gas phases were analyzed using an MI-1201 M mass spectrometer.

The tritium was measured using a proportional gas counter with an operating volume of 4 liter without enrichment (concentration) at the Pacific Oceanological Institute of the Far East Branch of the Russian Academy of Sciences. Tritium has been measured at the Pacific Ocean Institute of FEB RAS by counting $\beta$-decay in a liquid scintillation counter. The preliminary enrichment in two stages was carried out before the measurement. This allowed increasing the sensitivity limit to $0.03 \mathrm{TU}$.

\section{Chemical Composition of Groundwater}

Representative results of the chemical analyses of the studied waters are shown in Table $\mathbf{1}$. Two chemically distinct groundwater types occur in the study area: $\mathrm{Ca}-\mathrm{Mg}-\mathrm{HCO}_{3}$ and $\mathrm{Na}-\mathrm{HCO}_{3}$ waters (Figure 2). Shallow samples are Ca-Mg- $\mathrm{HCO}_{3}$ type water and the deeper samples are $\mathrm{Na}-\mathrm{HCO}_{3}$ type water. The shallow water typically has a total dissolved solid (TDS) content less than $400 \mathrm{mg} / \mathrm{L}$, $\mathrm{pH} 4.9-5.8$ and a molar $\mathrm{Ca} / \mathrm{Mg}$ ratio of about 0.94. $\mathrm{Na}-\mathrm{HCO}_{3}$ groundwater occurs beneath Ca-Mg- $\mathrm{HCO}_{3}$ water and has a very high TDS up to $14,000 \mathrm{mg} / \mathrm{L}, \mathrm{pH}$ $7.2-7.5$.

Table 1. Representative groundwaters and surface water chemical and isotopic analyses. Units for all dissolved components are in $\mathrm{mg} / \mathrm{l}$.

\begin{tabular}{|c|c|c|c|}
\hline Parameter & River Punchi & $\mathrm{Na}-\mathrm{HCO}_{3}$ groundwater & $\mathrm{Ca}-\mathrm{Mg}-\mathrm{HCO}_{3}$ groundwater \\
\hline $\mathrm{pH}$ & 6.1 & 7 & 5.3 \\
\hline TDS & 89.1 & 10,100 & 330 \\
\hline $\mathrm{Na}$ & 12.9 & 2400 & 17 \\
\hline $\mathrm{Mg}$ & 1.8 & 57.3 & 20 \\
\hline K & 2.9 & 46.4 & 0.93 \\
\hline $\mathrm{Ca}$ & 6.5 & 113 & 29 \\
\hline $\mathrm{SO}_{4}$ & 6 & 3 & 3.5 \\
\hline $\mathrm{Cl}$ & 7.1 & 109 & 1.2 \\
\hline $\mathrm{HCO}_{3}$ & 51.9 & 7300 & 229 \\
\hline $\mathrm{F}$ & NA & 0.4 & 0.1 \\
\hline $\mathrm{Al}$ & 0.001 & 0.002 & 0.078 \\
\hline B & NA & 66 & 0.16 \\
\hline $\mathrm{SiO}_{2}$ & 23 & 9.77 & 18.5 \\
\hline $\mathrm{Fe}$ & 1.5 & 0.08 & 11.5 \\
\hline $\mathrm{Mn}$ & 0.01 & 0.007 & 0.26 \\
\hline $\mathrm{Ba}$ & 0.019 & 0.006 & 0.068 \\
\hline $\mathrm{Sr}$ & 0.09 & 0.03 & 0.11 \\
\hline $\mathrm{Li}$ & 0.005 & 2.1 & 0.006 \\
\hline $\mathrm{Cu}$ & 0.008 & 0.142 & 0.002 \\
\hline $\mathrm{Rb}$ & 0.002 & 0.07 & 0.001 \\
\hline $\mathrm{Br}$ & n.a. & 0.146 & 0.07 \\
\hline I & n.a. & 0.042 & 0.003 \\
\hline Cs & 0.0003 & 0.021 & 0.002 \\
\hline Co & n.a & 0.0003 & 0.002 \\
\hline V & 0.003 & 0.0023 & 0.0003 \\
\hline$\delta \mathrm{D}, \%$ & -110 & -69 & -103 \\
\hline$\delta^{18} \mathrm{O}, \%$ & -14.4 & -25.2 & -14.2 \\
\hline${ }^{3} \mathrm{H}, \mathrm{TE}$ & 29.3 & 6.0 & 27.6 \\
\hline
\end{tabular}

n.a.-not analysed. 


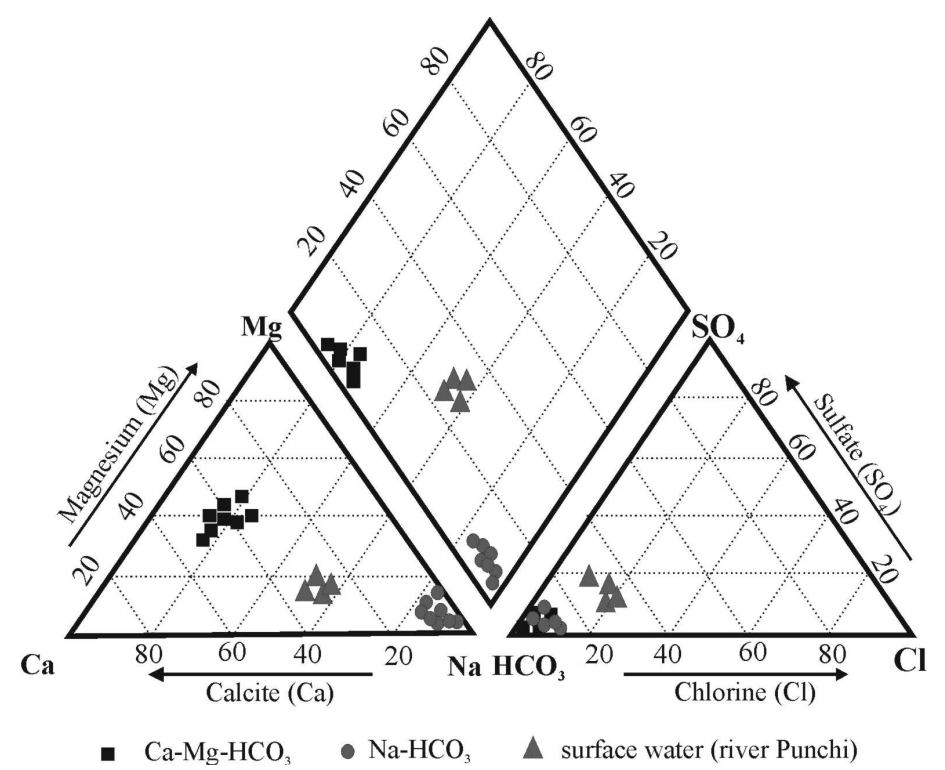

Figure 2. Trilinear diagram of analysis of surface and groundwater, illustrating the principal water types.

The analysis of the chemical composition of the ground and surface waters (Punchi River) showed that their TDS increases from the river waters through the Ca-Mg- $\mathrm{HCO}_{3}$ waters to the $\mathrm{HCO}_{3}$-Na waters. Obviously, the main increase in the salinity was caused by the influx of two components: hydrocarbonate ions and sodium cations. The calculated correlation coefficients (r) are 0.99 for the hydrocarbonate ion and 0.98 for sodium.

Note that the sodium waters have elevated contents of the following components: $\mathrm{Cl}^{-}(109-120 \mathrm{mg} / \mathrm{l}), \mathrm{Li}^{+}$ (up to $3.5 \mathrm{mg} / \mathrm{l}$ ), B (50 - $60 \mathrm{mg} / \mathrm{l}$ ), $\mathrm{Sr}^{2+}$ (up to $0.3 \mathrm{mg} / \mathrm{l}$ ), and $\mathrm{Br}^{-}\left(0.15 \mathrm{mg} / \mathrm{l}\right.$ ), as well as $\mathrm{I}^{-}$(about $0.04 \mathrm{mg} / \mathrm{l}$ ). The calcium-magnesium waters show high contents of $\mathrm{Fe}_{\text {tot }}$ (up to $13 \mathrm{mg} / \mathrm{l}$ ), $\mathrm{Mn}^{2+}$ (up to $0.6 \mathrm{mg} / \mathrm{l}$ ), $\mathrm{Ba}^{2+}$ (up to 0.2 $\mathrm{mg} / \mathrm{l})$, and $\mathrm{Si}\left(\mathrm{SiO}_{2}\right.$ about $\left.80 \mathrm{mg} / \mathrm{l}\right)$. Both the waters show a positive correlation between the potassium and lithium contents with a correlation coefficient of 0.993 , between the calcium and magnesium with $r=0.97$, between the silica and iron with $r=0.92$, and between the potassium and calcium with $r=0.98$. This indicates that, in spite of such strong differences in the concentrations, these elements are supplied both in the Ca-Mg- $\mathrm{HCO}_{3}$ and $\mathrm{Na}-\mathrm{HCO}_{3}$ groundwaters from water-bedrock interaction. The $\mathrm{CO}_{2}$ influx in the water system shifts the $\mathrm{pH}$ toward lower values, thus producing a more aggressive environment and, correspondingly, more intense dissolution of the host rocks. The negative correlation of silica with calcium, sodium, and potassium presumably indicates that the dissolution of the primary aluminosilicates and the influx of the major components in the water were accompanied by intense removal of silicon.

The enrichment of the Ca-Mg- $\mathrm{HCO}_{3}$ waters in trace components ( $\mathrm{Sr}, \mathrm{Ba}, \mathrm{Mn}, \mathrm{Fe}, \mathrm{Co}$, and $\mathrm{Ni}$ ) was caused by the leaching of the elements from silicates and aluminosilicates that compose the basaltic sequence. The elevated contents of $\mathrm{Li}, \mathrm{B}$, and $\mathrm{Sr}$ in the $\mathrm{Na}-\mathrm{HCO}_{3}$ waters were related to the intense leaching of these components from the sandstones and shales of the water-bearing complex in the presence of $\mathrm{CO}_{2}$. The analysis of the chemical composition of both the groundwaters during the past dozen years indicates stable contents of all the major components. However, the waters of the $\mathrm{Na}-\mathrm{HCO}_{3}$ type show a steady increase in their B and Sr contents.

The proportions of the main components (Table 2) indicate that the $\mathrm{Na}-\mathrm{HCO}_{3}$ waters were not contributed by marine sedimentation waters and that both the types are infiltration meteoric waters.

The molar $\mathrm{Sr}^{2+} / \mathrm{Ca}^{2+}$ ratio varies from 0.006 in the calcium-magnesium waters to 0.024 in the sodium waters. The obtained data are close to the molar $\mathrm{Sr}^{2+} / \mathrm{Ca}^{2+}$ ratio in shales (0.007) (Krauskopf, 1979) [2] and sodium feldspars (0.01 - 0.02) (Smith, 1974) [3]. The increase in the molar $\mathrm{Sr}^{2+} / \mathrm{Ca}^{2+}$ ratio with increasing TDS presumably resulted from the precipitation of calcite and dissolution of sodium feldspars.

Concentration of rare earth elements for both types of groundwater and surface water were determined from filtered samples and then as unfiltered samples. The REE abundance in the all studied waters is listed in Table 2. Shale-normalized plots of the REEs in these waters are shown in Figure 3. For comparison the earlier publicized data on concentration REE in the Miocene basalts (Martynov, 1999) [4] was also added on this plot. In this 
Table 2. REE abundance (ppb) in the water samples from the Muhen river catchment.

\begin{tabular}{cccccc}
\hline & \multicolumn{2}{c}{${\mathrm{Na}-\mathrm{HCO}_{3}}$} & \multicolumn{2}{c}{ Ca-Mg-HCO } & \multicolumn{2}{c}{ Muhen river } \\
\cline { 2 - 5 } $\mathrm{La}$ & 1 & 2 & 1 & 2 & 0.53 \\
$\mathrm{Ce}$ & 0.49 & 0.025 & 0.54 & 0.345 & 0.517 \\
$\mathrm{Pr}$ & 0.469 & 0.001 & 0.58 & 0.435 & 0.52 \\
$\mathrm{Nd}$ & 0.502 & 0.001 & 0.52 & 0.087 & 0.222 \\
$\mathrm{Sm}$ & 0.157 & 0.082 & 0.487 & 0.3 & 0.062 \\
$\mathrm{Eu}$ & 0.047 & 0.025 & 0.133 & 0.099 & 0.597 \\
$\mathrm{Gd}$ & 0.6 & 0.093 & 0.61 & 0.127 & 0.15 \\
$\mathrm{~Tb}$ & 0.132 & 0.049 & 0.198 & 0.179 & 0.601 \\
$\mathrm{Dy}$ & 0.601 & n.d. & 0.61 & n.d. & 0.118 \\
$\mathrm{Ho}$ & 0.105 & 0.103 & 0.213 & 0.17 & 0.527 \\
$\mathrm{Er}$ & 0.53 & 0.008 & 0.54 & 0.032 & 0.164 \\
$\mathrm{Tm}$ & 0.162 & 0.157 & 0.235 & 0.21 & 0.586 \\
$\mathrm{Yb}$ & 0.588 & n.d. & 0.598 & 0.0079 & 0.215 \\
$\mathrm{Lu}$ & 0.148 & 0.207 & 0.276 & 0.221 & 0.597 \\
$\mathrm{Y}$ & 0.598 & 0.013 & 0.61 & 0.027 & 0.532 \\
\hline
\end{tabular}

Note: 1-unfiltered samples; 2-filtered samples.

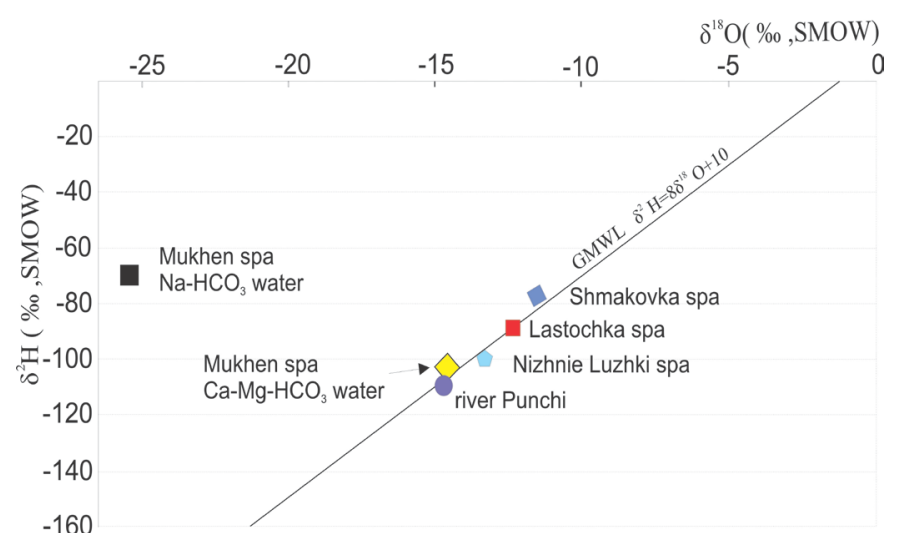

Figure 3. Variations of the oxygen and hydrogen isotopes in the waters from the boreholes of the Punchi area of the Mukhen deposit, the Punchi River, and the high $\mathrm{p} \mathrm{CO}_{2}$ groundwaters of Primorye (Chelnokov et al., 2013) [9].

paper, we normalize to North American Shale Composite (NASC) data taken from Hannigton \& Shelkovitch, 2001. Shale-normalized REE plots for all water samples are flat to slightly enriched in the HREEs.

The unfiltered samples general indicate higher concentrations than filtered ones, with larger variations for the HREE. In all samples the REE concentration becomes greater with increasing atomic number. The observed enrichment in the HREEs compared to the LREEs is believed to result from formation of stronger-carbonate complexes with increasing atomic number (Lee and Berne, 1993) [5]. Cerium anomalies were clearly found in the REE patterns of the filtered samples (Figure 4), whereas slight negative Ce anomalies are present in surface and unfiltered samples. In the samples of basalts samples (Martynov, 1999) [4] Ce anomaly is also absent. This reflects the reducing conditions of the underground environment where the both types of groundwater evolved. Positive Eu anomalies are evident for all water and basalt samples.

The REE concentration and shale-normalized signature for both types of groundwater are alike and closely resemble the REE signature of basalt rocks from northern Sikhote-Alin. This is likely related to a common path 


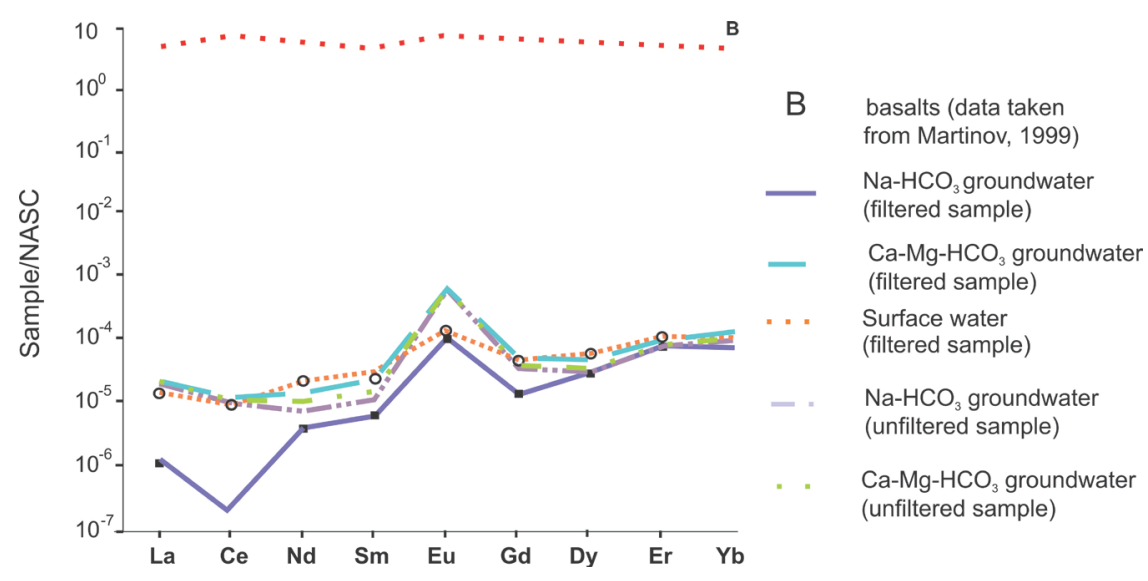

Figure 4. Shale normalized REE profiles of investigated waters.

of groundwater evolution via basalts.

\section{Chemical Composition of Gas}

The gas of both boreholes is practically identical in its chemical composition and represents pure $\mathrm{CO}_{2}$ with an admixture of other gases of no more than $0.8 \%$ (Table 3). It was found that the gas composition at the Mukhen deposit is similar to that from other Far East deposits with high pressure $\mathrm{CO}_{2}$.

The gas factor, i.e., the gas/water volume ratio, varies for different aquifers. It accounts for approximately 3 in the low-TDS waters $\left(\mathrm{Ca}-\mathrm{Mg}-\mathrm{HCO}_{3}\right)$ with an average gas saturation of about $1.3 \mathrm{l} / \mathrm{s}$, whereas $\mathrm{Na}-\mathrm{HCO}_{3}$ waters have high gas saturation of about $6.5 \mathrm{l} / \mathrm{s}$ and a gas factor of $32-50$. In the 1990s, the associated gas from borehole 30 was utilized for food and technical purposes. The partial pressure of $\mathrm{CO}_{2}$ in the water was calculated to be 0.24 bar for borehole 3 and 0.47 bar for borehole 30 .

\section{Thermodynamic Simulation}

The equilibrium-disequilibrium conditions in the water-rock system were determined using Phreeqc (Parkhust, 1995) [6], Waterq 4f (Ball and Nordstrom, 1991) [7], and Aquachem 5.1 software (User Guide, 2005) [8]. The thermodynamic modeling showed that the Ca-Mg- $\mathrm{HCO}_{3}$ waters are undersaturated with respect to all the carbonate minerals, except for siderite (the saturation indexes are -2.5 for calcite, -2.6 for aragonite, -4.4 for dolomite, 0.7 for siderite, andvv -3.5 for strontianite), as well as with respect to sulfates (the saturation indexes are -3.6 for gypsum, -3.8 for anhydrite, and -3.6 for celestine), plagioclases (the saturation indexes are -5.7 for anorthite and -2.0 for albite), potassium feldspar (1.4), olivine $(-16.5)$, pyroxenes $(-10.7)$, and amorphous silicon $(-0.2)$. They are also oversaturated with respect to quartz (1.1) and clay minerals (7.9 and 7.0 are the saturation indexes for kaolinite and smectite, respectively). The insignificant oversaturation with respect to siderite is related to the high content of divalent iron in this type of water. The $\mathrm{HCO}_{3}-\mathrm{Na}$ waters are in equilibrium with quartz (0.5) and chalcedony (0.3); oversaturated with respect to all the carbonate minerals (the saturation indexes are 1.6 for calcite, 1.5 for aragonite, 3.2 for dolomite, 0.7 for siderite, and 0.9 for strontianite) and clay minerals (the saturation indexes are 7.0 for kaolinite and 6.1 for smectite); and undersaturated with respect to sulfate minerals, albite $(-1.6)$, anorthite $(-2.8)$, and chlorite $(-7.5)$.

The thermodynamic calculations show that both type of mineral waters are strongly unsaturated to the primary rocks and are in equilibrium with the clay minerals. However, the Ca-Mg-HCO of primary accumulation of calcium, which is supplied from Ca-bearing minerals of the bedrocks. Silicon is removed from the water by precipitation of secondary quartz, which fills fissures in the host rocks. In contrast, sodium groundwaters passed through the carbonate barrier and became oversaturated with respect to all the carbonate minerals. Hence, calcium is not accumulated in this type of water, being removed from the solution in the form of carbonates. At the same time, sodium is accumulated in the solution by leaching from primary aluminosilicates. The constant $\mathrm{CO}_{2}$ gradient provides a significant influx of this element in the water, because, as follows from the equation of albite dissolution in the presence of $\mathrm{CO}_{2}$, the $\mathrm{Na}^{+}$concentration in the solution posi- 
Table 3. Chemical and isotopic composition of gas from Mukhen spa.

\begin{tabular}{cccccccc}
\hline \multirow{2}{*}{ Type of water } & \multirow{2}{*}{$\mathrm{pCO}_{2}$} & \multicolumn{3}{c}{ Content, vol.\% } & \multicolumn{3}{c}{$\delta^{13} \mathrm{C}_{(\mathrm{PDB})}, \%$} \\
\cline { 3 - 8 } & & \multicolumn{1}{c}{$\mathrm{CO}_{2}$} & $\mathrm{~N}_{2}$ & $\mathrm{O}_{2}$ & Other & Esc. & Diss. \\
\hline Na- $\mathrm{HCO}_{3}$ & 0.47 & $99.4-99.7$ & $0.26-0.06$ & $0.01-0.07$ & 0.1 & -3.5 & -4.2 \\
$\mathrm{Ca}-\mathrm{Mg}-\mathrm{HCO}_{3}$ & 0.24 & $99.3-99.5$ & $0.39-0.64$ & $0.09-0.12$ & 0.05 & -4.38 & -4.62 \\
\hline
\end{tabular}

tively correlates with the gas pressure in the system.

The calculated saturation indexes are consistent with the mineral composition of the bedrocks. Secondary alterations of basalts are expressed in the replacement of the olivine and glass of the groundmass by iddingsite and clay minerals.

In the diagrams of the mineral stability, the surface and hydrocarbonate magnesium-calcium groundwaters are plotted in the kaolinite field, while the hydrocarbonate sodium groundwaters are plotted in the montmorillonite field.

\section{Isotopic Composition}

\subsection{Water Phase}

The study of the stable oxygen and hydrogen isotope data $\left(\delta \mathrm{D}, \delta^{18} \mathrm{O}\right)$ in the waters of boreholes 3 and 30 revealed their differences (Figure 4). The hydrocarbonate calcium-magnesium waters (borehole 3) are correspond to the meteogenic waters of the region $\left(\delta \mathrm{D}=0.103 \%, \delta^{18} \mathrm{O}=-14.2 \%\right.$; Punchi River: $\delta \mathrm{D}=-110 \%$, $\delta^{18} \mathrm{O}=$ $-14.4 \%$ ), and they lie close to the global meteoric water line (GMWL). At the same time, the isotopic data of the hydrocarbonate sodium waters (borehole 30$)$ significantly shift from the lines of meteoric waters $(\delta \mathrm{D}=$ $-70 \%$, $\delta^{18} \mathrm{O}=-25.2 \%$ ). Such a "negative shift" presumably results from an isotopic exchange between the water oxygen and the $\mathrm{CO}_{2}$ gas oxygen. This suggestion corresponds to the geological-hydrogeological conditions of the spa: the extremely high gas saturation of the mineral waters of this type, the yield of associated gas of 6.5 $\mathrm{l} / \mathrm{s}$, and the yield of water in the borehole of no more than $0.14 \mathrm{l} / \mathrm{s}$.

The ${ }^{3} \mathrm{H}$ value in the $\mathrm{Ca}-\mathrm{Mg}-\mathrm{HCO}_{3}$ groundwaters is $27.6 \mathrm{TE}$ which is very close to the surface waters of the Punchi River (29.3 TE), but the ${ }^{3} \mathrm{H}$ value in the $\mathrm{HCO}_{3}$-Na groundwaters is 4.5 times lower (6.0 TE). Our calculations of the residence time for both water types indicate that these waters are young enough with a circulation period of no more than 55 years, at the same time the $\mathrm{Ca}-\mathrm{Mg}-\mathrm{HCO}_{3}$ waters have shorter residence time then the $\mathrm{Na}-\mathrm{HCO}_{3}$ waters.

\subsection{Gas Phase}

The most controversial problem is the $\mathrm{CO}_{2}$ source for all the deposits of carbonic acid mineral waters. Three sources of gas components are typically considered: 1) $\mathrm{CO}_{2}$ influx from the mantle along deep-seated faults; 2) $\mathrm{CO}_{2}$ formation during metamorphism of carbonate matter, and 3) $\mathrm{CO}_{2}$ release during decomposition of organic matter. The genesis of $\mathrm{CO}_{2}$ at the Mukhen deposit was determined using the $\delta^{13} \mathrm{C}$ content. The works dedicated to carbonic acid waters with high $\mathrm{pCO}_{2}$ demonstrated that the $\delta^{13} \mathrm{C}$ can be used as an indicator of the $\mathrm{CO}_{2}$ source in this type of water [10] [11]. The obtained $\delta^{13} \mathrm{C}$ of the dissolved and associated gases was between $-3.5 \%$ and $-4.62 \%$, which indicates (Table 3 ) that the gas in both the boreholes has a common mantle source, because, according to some data (Blavoux and Dazy, 1990; Ciezkowski et al., 1992) [10] [11], the $\delta^{13} \mathrm{C}$ of gas of mantle origin is within $-8<0.13 \mathrm{C} \%<-4$. Additionally, it has been established that $\mathrm{CO}_{2}$ of organic origin has $\delta^{13} \mathrm{C} \mathrm{C} \%$ between -26 and -12 , whereas $\mathrm{CO}_{2}$ forming via decomposition of carbonates has a $\delta^{13} \mathrm{C}$ between $0 \%$ and $+2 \%$ o (Hiscock, 2005) [12]; i.e., the carbon isotopic composition of the studied gases is heavier than that of organic gases and lighter than that of marine carbonates. The He isotopic studies of some spas from northern and central Sikhote Alin and northeastern China also point to the deep-seated origin of the $\mathrm{CO}_{2}$. The comparison of the obtained data on the $\delta^{13} \mathrm{C}$ in the gas phase of the Mukhen spa with that of other deposits indicates a common mantle origin of the $\mathrm{CO}_{2}$. It is possible that regional faults presented in region are pathways for $\mathrm{CO}_{2}$ to the surface.

\section{Conclusions}

Detailed description of the geological and hydrogeological setting of the area together with the chemical data of 
surface and groundwater provided information about the origin and evolution of two types of groundwater found in the Muhen River catchment.

1) The intense supply of $\mathrm{CO}_{2}$ along deep-seated faults in the subsurface aquifers is the main factor responsible for the formation of the Mukhen spa. The obtained $\delta 13 \mathrm{C}$ (gas) data indicate that the gas in both the boreholes has a common mantle source, which is well consistent with the data on other high p $\mathrm{CO}_{2}$ spas of the Far East.

2) The mineral waters of both the geochemical types are of meteoric origin, and their geochemical composition was formed by water-rock-gas interaction. The formation of the Ca- $\mathrm{Mg}-\mathrm{HCO}_{3}$ groundwater occurred under intense water exchange owing to the interaction of meteoric waters with the host rocks. The sodium hydrocarbonate $\left(\mathrm{Na}-\mathrm{HCO}_{3}\right)$ waters were formed under conditions of retarded water exchange during the movement of meteoric waters at deep levels, where they interacted with host rocks (shales, sandstones, and granites) to change their chemical composition. During the chemical transformations, the waters passed through a carbonate barrier with the removal of calcium from the solution by precipitation of carbonates. This process was accompanied by the formation of clay minerals (kaolinite, montmorillonite), which provided sodium accumulation in the waters. The strong difference in TDS of the mineral waters was caused by the difference (by more than 10 times) in the partial gas pressure during the reactions.

3) Negative shift in $\delta^{18} \mathrm{O}$ of the hydrocarbonate sodium waters results from the $\mathrm{CO}_{2}-\mathrm{H}_{2} \mathrm{O}$ isotopic exchange at $\mathrm{CO}_{2}$ gas predominance over $\mathrm{H}_{2} \mathrm{O}$ (water).

\section{Acknowledgements}

This study was supported by grant of Russian Foundation for Basic Research (Project No 14-05-00171A).

\section{References}

[1] Thepkaia, N.A., Chelnokov, G.A., Chudaev, O.V. and Chudaeva, V.A. (2005) Hydrochemical Evolution of the Na$\mathrm{HCO}_{3}$ Type Groundwater from Northern Sikhote-Alin (Far East Russia). Proceedings of the 11th International Symposium on WRI-11, Balkema.

[2] Krauskopf, K.B. (1979) Introduction to Geochemistry. McGraw Hill, New York.

[3] Smith, J.V. (1974) Feldspar Mineralogy. Vol. 2, Chemical and Textural Properties, Springer, Berlin.

[4] Martynov, Y.A. (1999) Geochemistry of Basalts of Active Continental Margin and Mature Island Arcs (North-West Pacific). Vladivostok, Dalnauka, 215 p.

[5] Lee, J.H. and Byrne, R.H. (1993) Complexation of Trivalent Rare Earth Elements (Ce, Eu, Ga, Tb, Yb) by Carbonate Ions. Geochimica et Cosmochimica Acta, 57, 295-302. http://dx.doi.org/10.1016/0016-7037(93)90432-V

[6] Parkhurst, D.L. (1995) User's Guide to PHREEQC-A Computer Program for Speciation, Reaction-Path, Adjective Transport, and Inverse Geochemical Calculation. Water-Resources Investigation Report, 95-4227, Lakewood.

[7] Ball, J.W. and Nordstrom, D.K. (1991) User’s Manual for WATERQ4F with Revised Thermodynamic Data Base and Test Cases for Calculating Speciation of Minor, Trace and Redox Elements in Natural Waters. U.S. Geological Survey Open-File Report, 91-183.

[8] (2005) User's Guide AQUACHEM-A Computer Program for Speciation, Reaction-Path, Adjective Transport, and Inverse Geochemical Calculation. Waterloo.

[9] Chelnokov, G., Kharitonova, N., Bragin, I. and Vasil'eva, M. (2013) Deuterium, Oxygen-18 and Tritium in Precipitation, Surface and Groundwater in the Far East of Russia. Procedia Earth and Planetary Science, 7, 151-154. http://dx.doi.org/10.1016/j.proeps.2013.03.209

[10] Blavoux, B. and Dazy, J. (1990) Caracterisation D’une province a $\mathrm{CO}_{2}$ dans le basin du sud-est de la France. Hydrogeologie, 4, 241-252.

[11] Ciezkowski, W., Groning, M., Lesniak, P., et al. (1992) Origin and Age of Thermal Waters in Cieplice Spa, Sudeten, Poland, Inferred from Isotope, Chemical and Noble Gas Data. Journal of Hydrology, 140, 89-117. http://dx.doi.org/10.1016/0022-1694(92)90236-O

[12] Hiscock, K. (2005) Hydrogeology Principles and Practice. Blackwell Publishing, Oxford. 